ISSN 1991- 8690

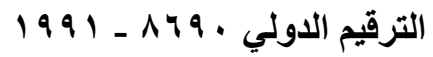

Website: http://jsci.utq.edu.iq

Email: utjsci@utq.edu.iq

\title{
Antibacterial Activity of The Nucleoside Antibiotic (NA) Isolated from Streptomyces alboflavus
}

\author{
Zainab T.K. Aldaly * Kawther M. Hawaz** Amin A. Al-Sulami*** \\ *College of Pharmacy - Pharma. And Cli. Pharmacy Dep. - Basrah University \\ ${ }^{* *}$ College of Science - Biol. Dep. - Basrah University \\ ${ }^{* * *}$ College of Education- Biol. Dep. - Basrah University
}

\begin{abstract}
During this study a new antibiotic was isolated from Streptomyces alboflavus which was active against Gram-positive and Gram-negative bacteria. The isolate antibiotic was white crystalline powder at $(28-30) \mathrm{C}^{\circ}$. Physicochemical properties were studied includes TLC, IR spectroscopy and Uv spectrum as well as color tests, all these studies indicate that the antibiotic produced by Streptomyces $s p$. Is a nucleoside antibiotic and gave the name (NA).The minimal inhibitory concentration of produced nucleoside antibiotic were determined against five standard gram positive positive and gram negative bacteria with MIC value ranged (2-25) $\mu / \mathrm{ml}$.
\end{abstract}




\section{Introduction:}

The low abundance of natural products containing fluorine ensures that drugs containing this element are processed as xenobiotics when they encounter biological system. An exception is the first fluoroorganic substance extracted from the South African gifblar shrub(Dichapetalum cymosum ), fluoroacetic acid ( 6,3), which mimics acetic acid so closely that it can substitute it in krebs cycle .Since that about adozen natural products containing fluorine have been isolated including the antibiotic nucleocidin isolated from Streptomyces calvus (2,5). One of the most important class of antibiotics produced by streptomyces bacteria are nucleoside antibiotics which are glycosylamines consisting of a nucleobase (often referred to as simply base) bound to a ribose or deoxyribose sugar via a beta-glycosidic linkage

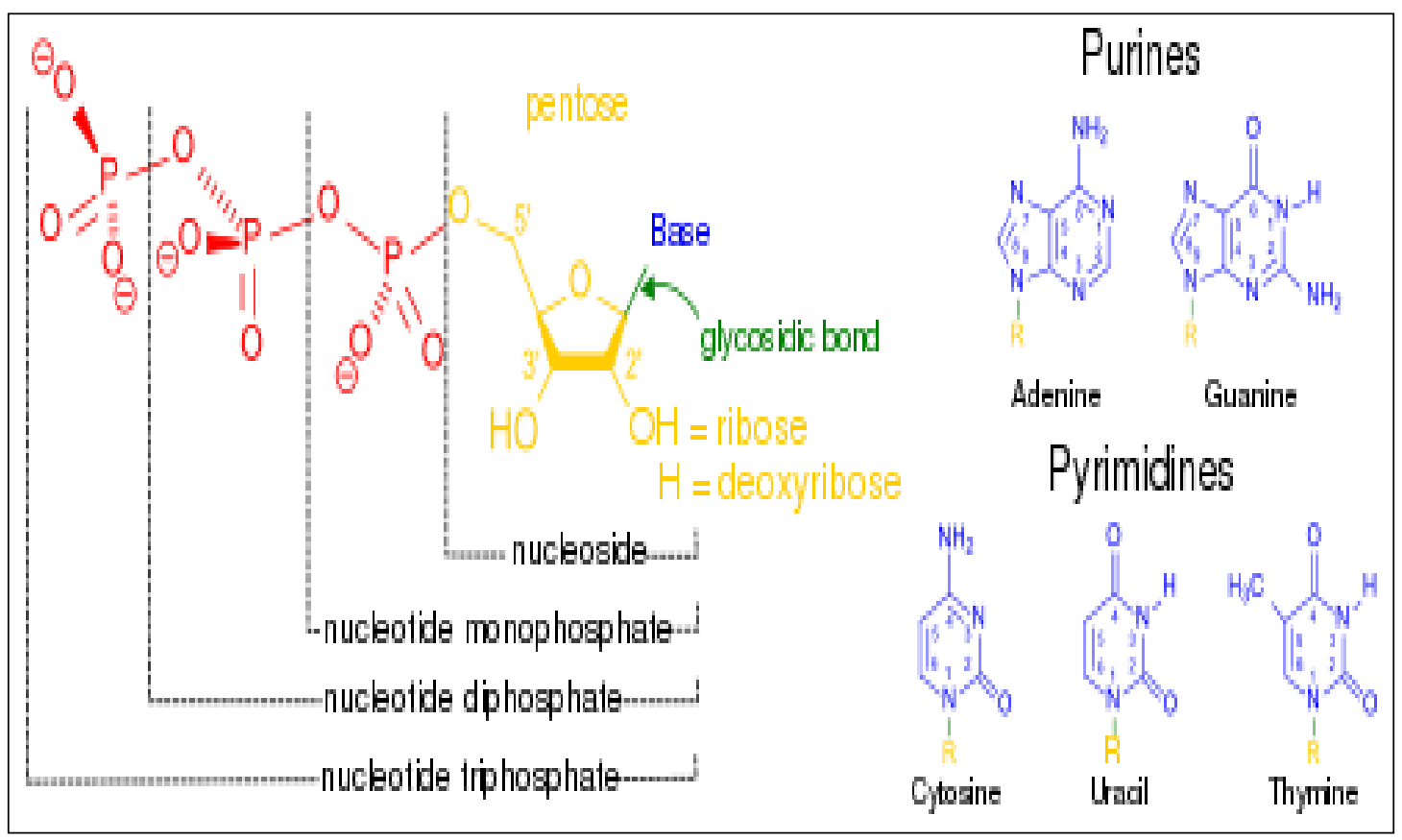

Figure (1): The structure elements of the nucleosides and the phosphate group bearing nucleotides

Nucleoside and nucleotidechemistry had importance in several fields of research since the elucidation of the double-helical structure of DNA by Watson and Crick in 1953(k) in natural product chemistry, diverse group of nucleoside compounds had been found in fermentation media of microorganism. Biological activities of nucleoside and nucleotid. Compounds include antibacterial, antifungal, antitumor antiviral, herbicidal, insecticidal , immunostimulating and immunosuppressive properties $(8,9,10,20)$.Incorporation of fluorine in drugs allows simultaneous modulation of electronic ,lipophilic and steric parameters, all of which can critically influence both the pharmacodynamic and pharmacokinetic properties of drugs $(4,7)$. 
The purpose of the present study was isolated a nucleoside antibiotic from Streptomyces alboflavus and determined the antimicrobial activity of this antibiotic against gram positive and gram negative bacteria.

\section{Materials and methods}

The production strain: Streptomyces alboflavus was isolated from soil in Southern of Iraq (14). Apure culture of the strain was maintained at $28 \mathrm{C}^{\circ}$ for laboratory on Actinomyces isolation agar .It was also preserved in $5 \%$ glycerol at $4 \mathrm{C}^{\circ}$.

\section{Target organisms:}

Escherichia coli ( NCTC 5933), Bacillus subtillus ( PCI219), Klebsiella pneumoniae (ATCC10031) , Proteus vulgaris (NCTC4175), Staphylococcus aureus ( NCTC6571), standard bacteria were obtained from H.K.Mehdi, College of Sci. Biology Dept. Basrah University.

\section{Fermentation:}

Aloopful of cultur of S. alboflavus was inoculated into aflask containing $50 \mathrm{ml}$ of the medium consisting of $1.5 \mathrm{~g} / 100 \mathrm{ml}$ starch, $2 \mathrm{~g} / 100 \mathrm{~m}$ malt extract (difco).PH was adjusted at 7.0, the flask was incubated at $28 \mathrm{c}^{\circ}$ for 3 days on a rotary shaker at 180 $\mathrm{rpm}, 5 \mathrm{ml}$ of the culture medium was transferred into $500 \mathrm{ml}$ flask containing $100 \mathrm{ml}$ of the fermentation medium consisting of $1.25 \%$ corn steep liguor, $1.0 \%$ mannitol , $0.2 \%$ Sodium chloride, $0.2 \%$ dibasic ammonium phosphate, $0.025 \%$ magnesium sulfate, $0.05 \%$ dipotassium phosphate, $0.15 \%$ monopotassium phosphate ,in tap water. The $\mathrm{pH}$ of medium was 6.9. Fermentation was carried out for $96 \mathrm{hr}$ at $28 \mathrm{c}^{\circ}$ on a rotary shaker (180rpm.), (19).

\section{Extraction and Isolation}

The fermented broth was extracted from the culture medium at $\mathrm{pH} 7.0$ by adsorption onto carbon (charcoal), and was eluted with acetone-water (95:5), lyophilized, dissolved in acetone-water (1:1) and passed through another charcoal. The eluted material was lyophilized and dissolved in 0.06 NHCL and the $\mathrm{pH}$ was adjusted to $\mathrm{pH} 4.0$ and lyophilized, disolved in methanol and filtered. Nucleoside antibiotic (NA) was readily obtained after lyophilized (19). NA antibiotic was tested by using thin layer chromatography (TLC) plates, acetone water (1:1) was used as a solvent .The TLC plates were exposed to iodine vapors to develop the antibiotic. Ultra Violet (UV) spectrum was recorded on Shimadzu UV Spectrophotometer, sample of (AN) was dissolved in methanol and the spectra were recorded at 200-400 $\mathrm{nm}$.The infrared spectra were recorded on Shimadzu- IR model, the spectra were scanned in the 400 to $4000 \mathrm{~cm}$ range, the spectra were obtained using potassium bromide pellet technique.The antibiotic was tested with specific color tests.

\section{Antibiotic assay:}

Antibacterial activity was determined using agar diffusion method ( 1 )against $E$. coli and $S$. aureus, control experiment was set up with water only, the minimal Inhibitory concentration of the purified antibiotic was assayed by paper-disk method (18) , against gram positive and negative bacteria, the antimicrobial activity was estimated by measuring the diameter of inhibition zone.

\section{$\underline{\text { Results and Discussion }}$}

NA antibiotic was obtained as a white crystalline powder (Fig 2) with the melting 
point of 142-144, Rf value 0.8,UV spectrum shown the present two at $245 \mathrm{~nm}$ and $281 \mathrm{~nm}$ which may attributed to $\pi \rightarrow \pi^{*}$ electronic transition of aromatic system of adenine ring (Fig 3).

IR spectrum indicated the presence of $\mathrm{NH} 2$ and $\mathrm{OH}$ groups stretching in $3450 \mathrm{~cm}$, aliphatic C-H stretching in 2929, 2858 , aliphatic $\mathrm{C}-\mathrm{H}$ bending in 1434 , Asymmetric $\mathrm{S}(=\mathrm{O})_{2}$ stretching in 1375, Symmetric $\mathrm{S}(=\mathrm{O}) 2$ stretching in 1118 and C-O,C-N stretching in 1238,1024.fig (4). NA gives positive reaction with each of the tests (Table - 1).

Table -1: Results of color tests

\begin{tabular}{|c|c|}
\hline Test & Results \\
\hline Nucleoside & + \\
\hline flourid & + \\
\hline Bial & + \\
\hline
\end{tabular}

The chemical tests showed appearance of a complex blue-green color in bial test which indicate the presence of pentose sugar and also nucleoside group by using nucleoside test, while the appearance of white color in the fluoro test indicate the presence of fluoride ion in the structure of isolated antibiotic. The location of this ion in the structure of NA antibiotic may confirm that the antibiotic with clinical importance because the incorporation of fluorinated sugar residues into nucleosides has provided a number of potent therapeutic activity mainly anticancer and antiviral( 17,16$)$.From the results of IR spectrum and the color tests we can ensure that the structure of isolated antibiotic belongs to nucleoside antibiotic groups . The antibiotic activities of NA was summarized in ( Table-2), this antibiotic had antimicrobial activities against Gram positive and negative bacteria , the result of minimum inhibitory concentration was shown in table-3, all the bacteria studied were sensitive to NA Antibiotic . MIC of NA were between $(2-25) \mu \mathrm{g} / \mathrm{ml}$.

Table -2: Antimicrobial activity of the antibiotic

\begin{tabular}{|l|c|}
\hline Test micro-0rganism & Concentration $\mu \mathrm{g} / \mathrm{ml}$ \\
\hline Escherichia coli & 20 \\
\hline Staphylococcus aureus & 30 \\
\hline
\end{tabular}

Table -3: MIC of the antibiotic from $S$. alboflavus against different target organisms.

\begin{tabular}{|l|c|}
\hline Target organisms & MПC in $\boldsymbol{\mu g} / \mathbf{m l}$ \\
\hline Bacillus subtiles & 3 \\
\hline Escherichia coli & 3 \\
\hline Staphylococcus aureus & 2 \\
\hline Klebsiella pneumoniae & 5 \\
\hline Pseudomonas & 25 \\
\hline
\end{tabular}

NA activity may be due to the structural mimicry between the nucleoside antibiotics and the building block of the genetic material which cause inhibition replication (15).These results indicates that Gram positive bacteria were most sensitive to the antibiotic than Gram negative bacteria (Table2,3), (Fig 5 ,6).Gram negative bacteria resistance to NA may be due to apermeability barrier against this agent the lipid bilayer of the outer memberane though to be a common barrier in Gram -negative bacteria as outer membrane allows the penetration of only small hydrophilic molecules, (13) .In addition to difference in cell wall studies on the nucleoside antibiotic Blasticidin declairs the presence of genes called deaminase genes which coded to enzyme deaminase this enzyme converts the antibiotic Blasticidin to inactive and non toxic to compound (12). 


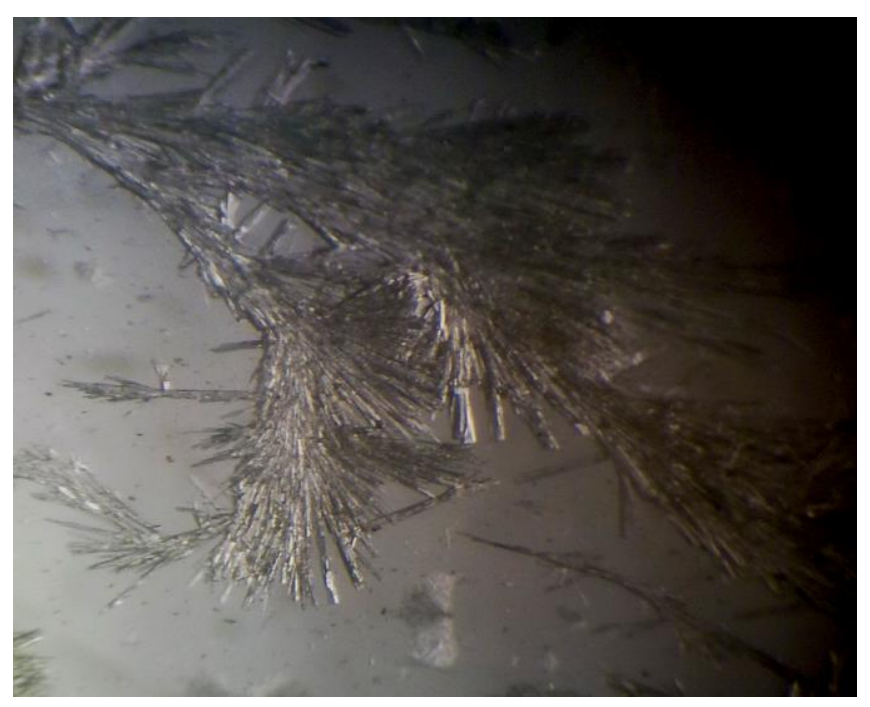

Figure (2) White crystalline of NA 16X

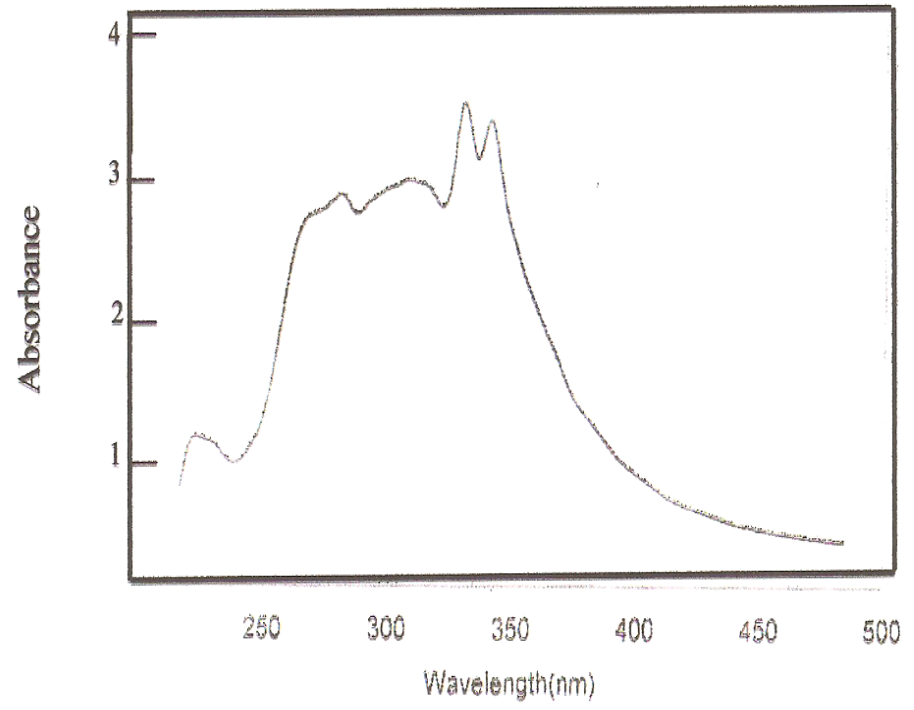

Figure (3): UV spectrum of NA 


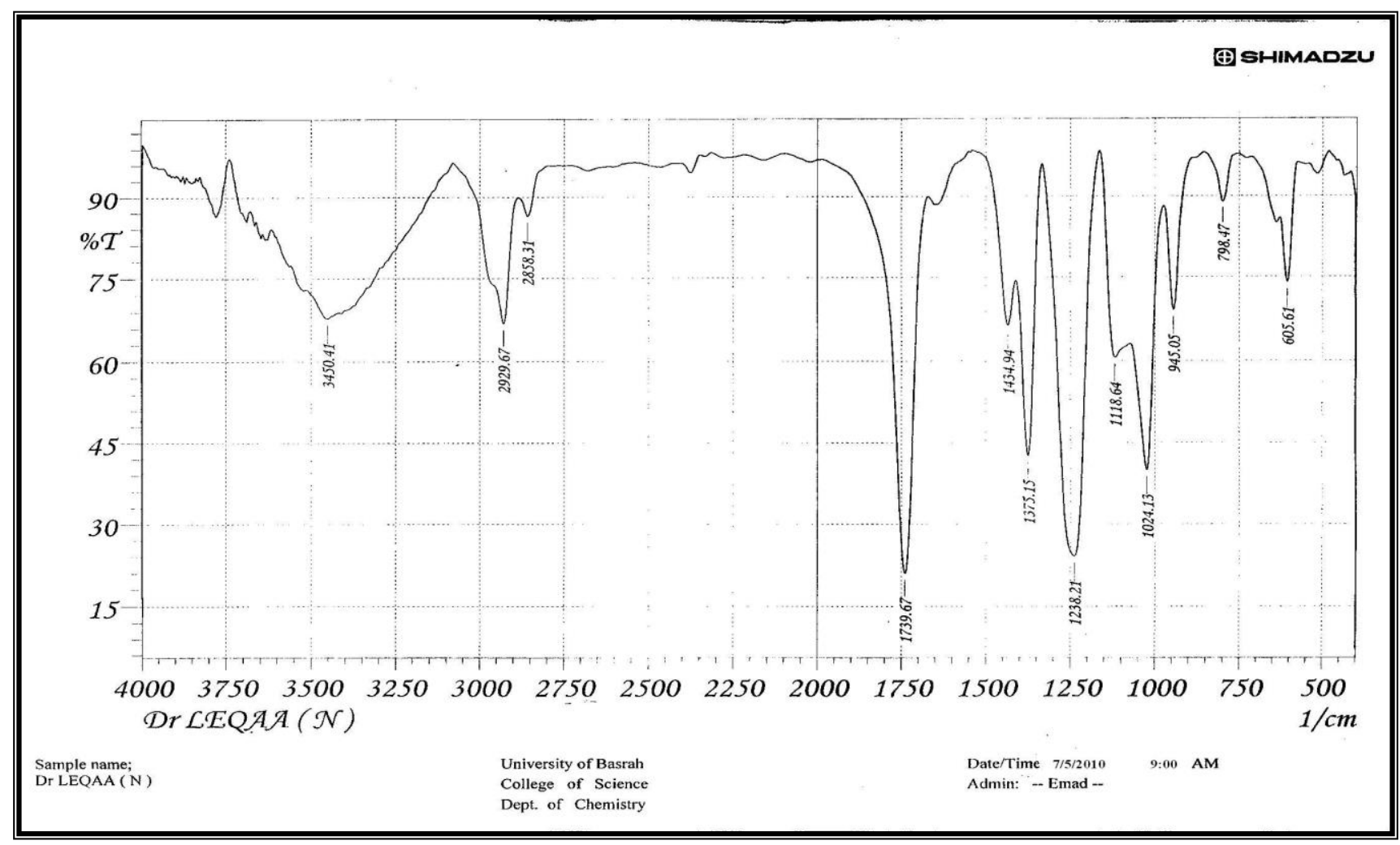

Figure (4) Infra-red spectra of NA antibiotic

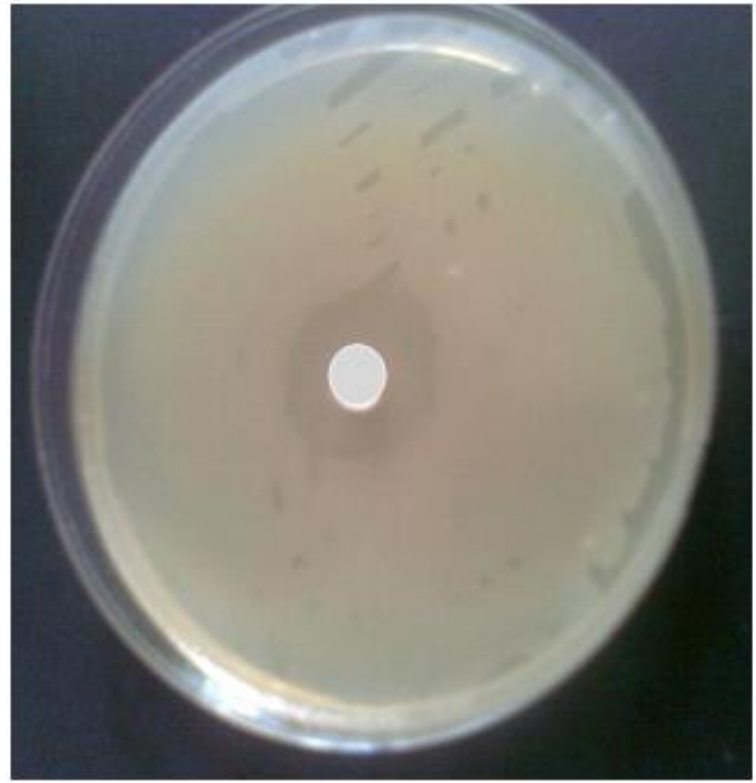

Figure (5): Activity of NA on E. coli

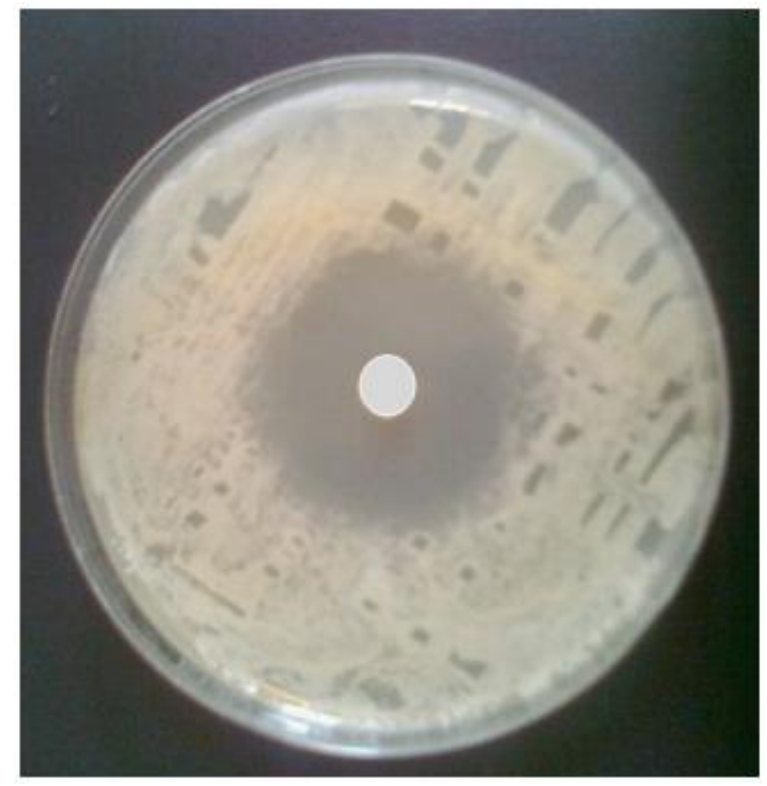

Figure (6): Activity of NA on S. aureus 


\section{$\underline{\text { References }}$}

1.Bauer,A.W.;Kirby,W.N. Sherris ， J.S. and Turch,M. (1966). Antibiotic Susceptibility Testing by a standarization single discs.Am .J.Clin .Pathol.45 , 493-496.

2.Blake,D.;Robert,D.And Crailg,S.(1997) . Fluorinated Orangics in the Biosphere.EnvironmentalScience\&Technology.31,24452454.

3.Cormac,D.M.;Christoph,S. And David,O.(2003) . Fluorinated natural products: the biosynthesis of fluoroacetate and 4-fluorothreonine in Streptomyces cattleya Chemos phere

$52,455-461$.

4.Dini,C.;Diodier-Laurent,

S.Drochon

,N.;Feteanus, S.;Guillot,J.C., Monti,F.;Uridat ,E.; Zhang ,J. And Aszodi,J. Bioorg. Med. Chem.Lett.,( 2002),12,1209.

5.Elliott,A.J.In:Hudlicky,A.E. $\quad$ Pavlath(Eds.) ,Chemistry of Organic Fluorine Compounds.II.A Critical Review,ACS Monograph 187,American Chemical Society, Washington, DC (1995) 11191125.

6.Fyaz,M.D.(2002). Important Fluorinated Drugs In Experimental and Clinical Use .J.Fluorine Chem.118, 27-33.

7.Hagan,D.O.and Harper,D.B. (1999) . Fluorine-containing natural products.J. Fluorine Chem.100, 127-133.

8.Hagan,D.O. ;Schaffrath, Igarashi, Y.; Ootsu, K.; Hiroyasu, O.; Fujita ,T.; Uehara, Y.and Furumai, T. (2005). Anicemycin aNew Inhibitor of Anchorage-independent Growth of Tumor Cells from Streptomyces sp. TP-A0648 . J.Antibiot. 88 ,322-326.

9.Isono,K.J. (1988).The Biosynthetic Pathway of the Aminonucleoside Antibiotic
Puromycin , as Deduced from the Molecular Analysis of the Pur Cluster of Streptomyces alboniger J. Antibiot., ,41,1711-1739.

10. Isono,K. (1991). Pharmacol.Ther., 52,269.

11..Isono,F.;Kodama,K. and Inukai,M.(1992). Antimicrob. Agents

Chemother.,36,1024.

12.Izumi,M.;Miyazawa,H.;Kamakura,T.;Yamag uchi,I.;Endo,T. and. Hanaoka,F (1991).Blasticidin S-Rssistance Gene (bsr):Anovel selectable marker for mammalian cells.Exp.Cell.Res197,229233.

13.Ken-ich, K and Timothy D. H.B. (2002). Recent advance in antimicrobial nucleoside antibiotics targenting cell wall biosynthesis. Nat. Prod. Rep. J. of Royal Society of Chemistery P: 252-245.

14.Mehdi,K.H.(1997) .Isolation ,Identification and development of Streptomyces aureofaciens Highly producing chloro tetracycline strain from soils of southern Iraq.ph.D.Thesis .College of sci.Basrah Univesity.

15.Michael ,E.and Peddie,V. (2006). Fluorinated Analogues of Biological Molecules: Accessing New Chemical, Physical and Biological Properties.Chemistry in New Zealand October. (Article) .

16. Michael,P.B.S.;Oonagh,S.Anders,R. Lars,B.and Jure,P.(2007)Deoxyri bonucleoside kinases Antibiotics in Severely Pathogenic Bacteria. Aug Antimicrobial Agents and chemotherapy. 327:2726-2732.

17.Pankiewicz,K.W.Carbohydr.Res. (2002) 327: 87-105.

18.Spooner,D,F.and Sykes,G.(1972). Labrotory assessment of antiba- cterial activity.In: Norris,J.R.And Ribbons,D.W.(ed). 


\section{J.Thi-Qar Sci.}

Method in Microbiology.Academic Press.

INC.Londan Ltd. 7B,211-276.

19.Thomase,S.O.;Lowery,J.A.AndSingleton,V.L .(1959).In:R.J.Suhadolk (1970).

Antibiotics.Wiley- Interscience, A division of John Wiley \& sons. 246-250 .
20.Yasunori,M.Masatoshi , A.And Yoshiharu ,S.(2006) Studies on novel Bacterial Inhibitors, A-500359s.J.Antibiot.59: 601606.

الفعاليه الضد بكتيريه للمضاد النيو كليوسيدي NA المعزول من بكتيريا

Streptomyces alboflavus

\section{الخلاصة}

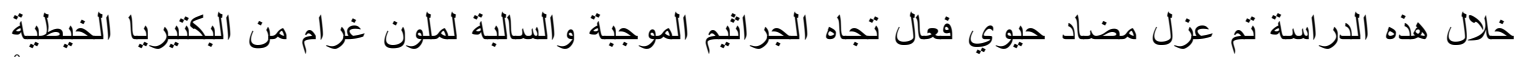
Streptomyces alboflavus

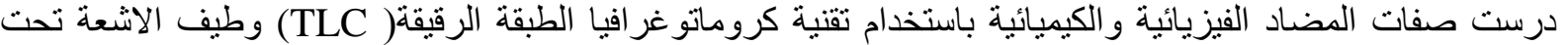

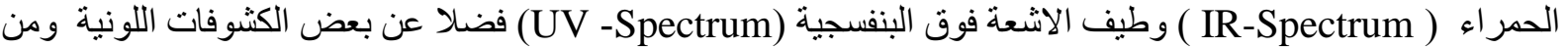

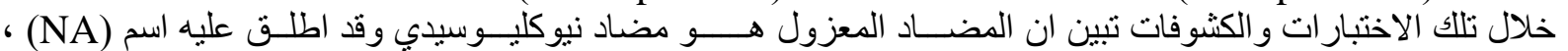

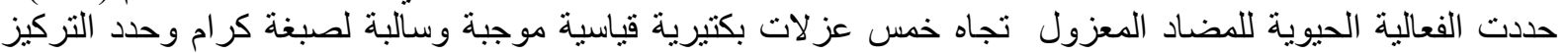
الأدنى المثبط (MIC) ، اذ نر اوحت قيمته بين( 2- 25) مايكروليتر /مل . 